DOI: $10.15503 /$ jecs20142.19.30

Journal of Education Culture and Society No. 2_2014

\title{
BETWEEN LÉVINAS AND ARENDT - PHILOSOPHICAL ORIGINS OF ALAIN FINKIELKRAUT'S REFLECTION ON THE OTHER AND THE EDUCATION
}

\author{
KATARZYNA LISZKA \\ Institute of Polish Philology, University of Wroclaw, pl. Nankiera 15, \\ Wroclaw, Poland \\ E-mail address: kasialiszka@poczta.fm \\ RAFAŁ WŁODARCZYK

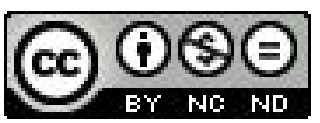 \\ Faculty of Pedagogy, University of Wroclaw, ul. J. W. Dawida 1, \\ Wroclaw, Poland \\ E-mail address: rwo@pedagogika.uni.wroc.pl
}

\begin{abstract}
A member of the generation of student revolt '68, Alain Finkielkraut is thought to be one of the most prominent intellectuals in France, taking part in public debates on several issues essential for Europe and the world. His assays, articles and books may be read as a complex commentary with a sound humanistic background to the condition of western culture as well as to current socio-political events. Our article focuses on revealing theoretical grounding of Finkielkraut's reflection in the philosophies of Emmanuel Lévinas and Hannah Arendt. We attempt to reconstruct the way Finkielkraut employs his critical apparatus built on their thought to the field of educational practices in order to present the specific perspective of educational research and to contribute to the knowledge produced by widely understood critical pedagogic.

Keywords: Wethics, politics, otherness, education, pedagogy, responsibility, justice, judgment, cultural anthropology

A member of the generation of student revolt '68, Alain Finkielkraut is thought to be one of the most prominent intellectuals in France, taking part in public debates on several issues essential for Europe and the world. His assays, articles and books may be read as a complex commentary with a sound humanistic background to the condition of western
\end{abstract}


culture as well as to current socio-political events. Our article focuses on revealing theoretical grounding of A. Finkielkraut's reflection in the philosophies of Emmanuel Lévinas and Hannah Arendt. We attempt to reconstruct the way A. Finkielkraut employs his critical apparatus built on their thought to the field of educational practices in order to present the specific perspective of educational research and to contribute to the knowledge produced by widely understood critical pedagogic.

In the first part of our paper, we present the main notions developed by $\mathrm{H}$. Arendt and E. Lévinas that also became essential for A. Finkielkraut's critical approach - which is the notion of Otherness, responsibility, justice, understanding of politics and public sphere. We attempt to grasp the connection between two crucial issues: his ethicalpolitical reading of E. Lévinas, as well as H. Arendt's thought and his critical approach applied to investigate educational practices, social-cultural situations, states and events. By doing so, we attempt to not only demonstrate the aptness and importance of Finkielkraut's readings of E. Lévinas and $\mathrm{H}$. Arendt that constitute considerable contributions to understanding both thinkers, but also the originality of his work that, as we believe, is of great relevance to the dilemmas of (post)modernity.

The second part is based on various efforts to illustrate with examples the way the notions derived at the level of philosophical thinking are translated into the educational and social-political mode of interpretation introduced by A. Finkielkraut. The necessarily selective presentation of examples starts with the issue of the contemporary crisis in education. Then we deal with A. Finkielkraut's concept of imaginary Jew, to pass on to the reflection on the idea of humanity and associated with the former criticism of the so called sentimental reason.

In all the aforementioned examples, the notion of Otherness, as we demonstrate in the context of intercultural education and western educational theory and practice, plays a crucial role, be it the reflection devoted to the Jewish identity or to the idea of humanity. In his analysis, an author of In the Name of the Other insists that the exaggerated interpretations of Otherness often lead to a crisis in many spheres of sociopolitical and educational practice, not to mention that they also lead to misreadings of Lévinas's thought. With the notion of humanity, A. Finkielkraut not only refers directly to Lévinas's philosophical thought on the notion of Otherness, but also to H. Arendt's political thinking, which seems easier to omit. To make the way H. Arendt and E. Lévinas provide Finkielkraut's commentary with a deep philosophical background more visible, we shall quote the answer given to his opponents, who we call the defenders of the Other at all costs: "(...) I would like to respond to them following Hannah Arendt, that it is not a man who lives on the Earth, but people in their infinite plurality, and following Lévinas, the philosopher of alterity par excellence, that there is always a danger in subjecting proper names to the rule of common names, even when we mean the Other" (Finkielkraut, \& Sloterdijk, 2005, p. 34).

At the symposium devoted to Emmanuel Lévinas organized by "Colloque des intellectuels juifs" at the end of the 90s, one of the sections was conducted by A. Finkielkraut. The title of this section was most likely "Éthique et politique", as this is what one of the chapters of the book publicized after the symposium was entitled. We will quote a piece of his opening speech concerning the large popularity of Lévinas's thought: "However there is often a price to pay for a success, namely, misunderstanding, ideological petrification, simplification and sloganization. The reception of Emmanuel Lévinas does not escape this rule: there is today the pious levinassism, which presents Lévinas as spokesmen for ethics and its priority over politics and ontological 
totalitarianism of politics" (1998, pp. 109-110). And as we can read further "Lévinas never presents ethics and politics as two attitudes, two forces, two rules or two antagonistic domains. Whereas certain continuators - who refer to his heritage in order to think, intervene, deconstruct and engage - have found in the responsibility for the other the new fundament of radical critics of all political systems that ever existed, for Lévinas politics is characterized by moderation" (1998, pp.109-110).

It is possible to read Finkielkraut's comment as a kind of expedient provocation, especially when seen beyond the context of his books; provocation he takes up in order to refresh the reception of Lévinas's thought in crisis. However, as we will attempt to explain here, the remark has been strongly inscribed in the logic developed in his critical approach from the beginning of the 80s. This approach is based on the tension between the ethical and the political oriented probing the public sphere. It is worth stressing that his approach, initiated with the book La sagesse de l'amour $(1984)^{1}$, has constantly been associated with his works for nearly 20 years. It is also worth stressing that this book has in a sense a unique place in the corpus of his works, as being entirely committed to the philosophical interpretation of Lévinas's thought. We should also remember that it is not only Lévinas who inspires Finkielkraut's critical approach, as he confesses in one of the interviews: "There are two types of authors: one we read and leave on the bookshelf and one we keep going back to because the world continuously leads us to their thought. Beside Lévinas, Kundera, and Heidegger, it is also Hannah Arendt who belongs to the second category. I never let her sleep - she is helping me to understand the world" (Finkielkraut, \& Simon-Nahum, 2005, p. 32).

Thus, beside Lévinas, it is also H. Arendt's political reflection that plays an important role in Finkielkraut's critical approach. It may seem that Lévinas's ethical thought is only completed by Arendt's political reflection and that it provides the entire perspective. But in fact both Finkielkraut's thought and the course of the section "Éthique et politique" challenge the relevance of this conclusion. We would rather say that according to Finkielkraut, Arendt and Lévinas synthesize these two components - ethics and politics. Even if this claim isn't controversial when relating it to Arendt ${ }^{2}$, it does not seem obvious when thinking of Lévinas.

It seems necessary to explain the meaning of the notion of politics we refer to, the connection between public sphere and power in the thought of both Arendt and Lévinas. Consider then the way Arendt explains the meaning of "public" in The Human Condition: "It means, first, that everything that appears in public can be seen and heard by everybody and has the widest possible publicity (1998, p. 50). Second, as she adds - the term "public" signifies the world itself, in so far as it is common to all of us and distinguished from our privately owned place in it. This world, however, is not identical with the earth or with nature, as the limited space for the movement of men and the general condition of organic life. It is related, rather, to the human artifact, the fabrication of human hands, as well as to affairs which go on among those who

La sagesse de l'amour (1984) has an unique place among his other writings as a record of his first encounter with Lévinas's philosophy but also as a book completely devoted to exploration of philosophical notions essential to Lévinas. (Finkielkraut and Sloterdijk, 2005, pp. 22-24).

2 Ethical-political issues are present in all Arendt's writings although great diversity of topics and ways of approaching them in works like The Human Condition, The Origins of Totalitarianism, Between Past and Future, Eichmann in Jerusalem and Responsibility and Judgment. 
inhabit the man-made world together. To live together in the world means essentially that a world of things is between those who sit around it; the world, like every inbetween, relates and separates men at the same time. The public realm, as the common world, gathers us together and yet prevents our falling over each other, so to speak" (1998, p. 52).

According to $\mathrm{H}$. Arendt, the public sphere can not be simply reduced to the sphere of struggle for political power and it also can not be identified with wielding power on the highest level of state or international life. H. Arendt underlies that "The space of appearance comes into being wherever men are together in the manner of speech and action, and therefore predates and precedes all formal constitution of the public realm and the various forms of government, that is, the various forms in which the public realm can be organized - and as a result - Power is what keeps the public realm, the potential space of appearance between acting and speaking men, in existence" (1998, pp. 199-200).

E. Lévinas presents a similar view in this matter: "Freedom is not realized outside of social and political institutions, which open to it the access to fresh air necessary for its expansion, its respiration, and even, perhaps, its spontaneous generation. Apolitical freedom is to be explained as an illusion due to the fact that its partisans or its beneficiaries belong to an advanced stage of political evolution. An existence that is free, and not a velleity for freedom, presupposes a certain organization of nature and of society" (Lévinas, 1992, p. 241).

To investigate A. Finkielkraut's approach to the question of politics and public sphere more closely, we shall initially refer to Lévinas's texts. In the preface to Totality and Infinity following Franz Rosenzweig (Lévinas 1992, p. 28), E. Lévinas announces his critical view on Hegel's philosophy. On the one hand, it is the subjectivity that is at stake here, subjectivity "founded in the idea of infinity". But on the other hand, it is also an apprehension of the subjectivity "not at the level of its purely egoist protestation against totality" and not at the level of fear of one's own death motivation. Thereby his conception of subjectivity finds itself in opposition not only to Georg W. F. Hegel, but also to Soren Kierkegaard and Martin Heidegger. In the context of the double opposition, E. Lévinas introduces „subjectivity as welcoming the Other, as hospitality" $(1992$, pp. 26, 27) and this is the very issue to which wide passages of Totality and Infinity have been devoted.

In this work, as well as in many others, Lévinas applies a phenomenological approach. This is why the model analyses take up so much space in the text. But phenomenological writings do not constitute an exhaustive representation of his philosophical output, for at the same time Lévinas as a Jewish thinker remains the author of other sorts of books, such as: Quatre lectures talmudiques, Du sacré au saint, L'au-delà du verset, À l'heure des Nations, Nouvelles lectures talmudiques and Difficile liberté. The aforementioned works differ from the philosophical one; not in the problems they address, but in the method of its presentation (cf. Lévy, 1999, pp. 8999). Therefore, those books are precious comparative sources for researchers who try to explore the various accents in Lévinas's philosophy. A. Finkielkraut is also familiar with those writings.

In Totality and Infinity, it is the relation between the I and the Other that remains the basic problem. A thorough description of this relation provides a starting point for further investigations. It is no wonder that the question of responsibility for the Other and service to the Other as components of hospitable subjectivity are in the 
foreground and push aside the question of the third (le tiers) and justice. However it should not be underestimated in a reliable reconstruction of his philosophical conception. According to A. Finkielkraut and many others, the consequences of a one-sided privilege of the responsibility are more than problematic.

If we believe the idea of responsibility to be central, we thereby close the possibility that Lévinas attaches to judgment: „The idea of infinity delivers the subjectivity from the judgment of history to declare it ready for judgment at every moment and, we shall show, called to participate in this judgment, impossible without it. The harsh law of war breaks up not against an impotent subjectivism cut off from being, but against the infinite, more objective than objectivity" (Lévinas, 1992, p. 25-26).

It is worth stressing that being "ready for judgment", mentioned above, is possible only when the subjectivity has an access to any frame of reference. In other words, giving a priority to the Other, and this is what the infinite responsibility demands, deprives the subject of the opportunity to limit violence which has its source in the Other. Nevertheless it will always compare what can't be compared, comparing the incomparable. If, beside Lévinas's phenomenological model, I am responsible for my fellowman as well as for the third (le tiers) and many others, the question is: who has priority? "The relation with the face in fraternity, where in his turn the Other appears in solidarity with all the others, constitutes the social order, the reference of every dialogue to the third party by which the $W e$ - or the parti - encompasses the face to face opposition, opens the erotic upon a social life, all signifyingness and decency, which encompasses the structure of the family itself"3 (Lévinas, 1992, p. 280). And as he adds in another passage: "I am therefore necessary for justice, as responsible beyond every limit fixed by an objective law. The I is a privilege and an election. The sole possibility in being of going beyond the straight line of the law, that is, of finding a place lying beyond the universal, is to be I" (Lévinas, 1992, p. 245).

In all his writings, Lévinas keeps reminding us of the importance of justice. As we can read in Otherwise than Being: or Beyond Essence: "The third party is other than the neighbor, but also another neighbor, and also a neighbor of the other, and not simply his fellow. What then are the other and the third party for one another? What have they done to one another? Which passes before the other? The other stands in a relationship with the third party, for whom I cannot entirely answer, even if I alone answer, before any question, for my neighbor. The other and the third party, my neighbors, contemporaries of one another, put distance between me and the other and the third party. (...) The third party introduces a contradiction in the saying whose signification before the other until then went in one direction. It is of itself the limit of responsibility and the birth of the question: What do I have to do with justice? A question of consciousness. Justice is necessary, that is, comparison, coexistence, contemporaneousness, assembling, order, thematization, the visibility of faces (...)" (Levinas, 1991, p. 157).

Lévinas explains it more closely with this passage: „It is not that the entry of a third party would be an empirical fact, and that my responsibility for the other finds itself constrained to a calculus by the "force of things". In the proximity of the other,

\footnotetext{
"Metaphysics, or the relation with the other, is accomplished as service and as hospitality. In the measure that the face of the Other relates us with the third party, the metaphysical relation of the I with the Other moves into the form of the We, aspires to a State, institutions, laws, which are the source of universality. But politics left to itself bears a tyranny within itself; it deforms the I and the other who have given rise to it, for it judges them according to universal rules, and thus as in absentia" (Lévinas, 1992, p. 300).
} 
all the others than the other obsess me and already this obsession cries out for justice, demands measure and knowing, is consciousness. (...) The other is from the first the brother of all the other men"4 (Levinas, 1991, p. 158).

To sum up, Lévinas does not claim that the Other has an unconditional priority for the sake of my responsibility for him. In spite of it, he claims that responsibility to the third and many others makes me decide between them - saying this he does not deny the validity of knowledge and ontology, but he derives its necessity from ethical ground. If the Other existed as the only One, not only my service would be exclusive but also my vigilance would be needless.

When translating his model structure of relation, the I-the Other on social thinking - Lévinas does not forget about pluralism and heterogeneity. So according to Lévinas, the complex and problematic relations between freedom, responsibility and justice are crucial, essential to the concepts of solidarity and fraternity. In a dialogue with Peter Sloterdijk Finkielkraut says: "The whole work of Lévinas protests against such petrification of alterity: «My liberty is not the last word, I am not alone», he writes. But nor is the Other, because there are not only the two of us. There is also, repeats Lévinas, the third party, with whom we abandon the last word in favor of endless asking the questions: what have been done to whom? Who is my neighbor? Who passes before the Other? «I must judge what I am responsible for in the first place? Dedication and sacrifice is not enough. Love needs wisdom". (Finkielkraut, \& Sloterdijk, 2005, pp. 149-150).

Responsibility as obligation to commitment means obligation to a reasonable service, to counteract injustice. Judgment is essential here inasmuch as it requires us to study whether the actions of the Other and every other are directed against other others. Similarly, the connection between ethics and politics through the central question of judgment is to be found in Arendt's thinking - the subject is responsible for the world, and his power to forgive and to promise are necessary elements of community life and the public sphere (cf. Arendt, 1998, pp. 236-247). While analyzing origins and functioning of totalitarianism Arendt manages to ask the question - perhaps the most important one for her - about the personal responsibility under dictatorship. This question resounds in The Origins of Totalitarianism (1973) as well as in the book which provoked numerous controversies, the outcry and multilateral attacks on H. Arendt, Eichmann in Jerusalem (1995). Perhaps the very turbulent history of reception of the report on the Nazi criminal trial lead her to articulate this problem directly (cf. Brudny, 2006, pp. 217236; Aschheim, 2001, pp. 205-277). “There are number of reasons why the discussion of the right or the ability to judge touches on the most important moral issue. Two things are involved here: First how can I tell right from wrong, if the majority or my whole

4 "My resistance begins when the harm he does me is done to the third party who is also my neighbor. It is the third party who is the source of justice, and thereby of justified repression; it is the violence suffered by the third party that justifies stopping the violence of the other with violence." (Lévinas 1998, p. 83); "in the relationship with another I am always in relation with the third party. But he is also my neighbor. From this moment on, proximity becomes problematic: one must compare, weigh, think ; one must do justice, which is the source of theory. (...) If equity is necessary, we must have comparison and equality: equality between those that cannot be compared" (Lévinas, 1998, p.82); „,The third party is also my other, also my neighbor. Who would be the first to speak ? Where does the priority lie? A decision must be made. The Bible requires justice and deliberation! From the heart of love, from the heart of mercy. One must judge, one must reach a conclusion" (Lévinas, 1994, p. 134). See also two essays opening his Difficult Freedom "Ethics and Spirit" and "A Religion for Adluts" (Levinas, 1990). 
environment has prejudged the issue? Who am I to judge? And second, to what extent, if at all, can we judge past events or occurrences at which we were not present?" (Arendt, 2003, pp. 18-19; cf. Arendt, 1993, pp. 227-264).

This way $\mathrm{H}$. Arendt tries to ask once again about the crucial issue - concerning not only the way Eichmann acted, but also direct and indirect forms of engagement of the individuals in functioning of the totalitarian state apparatus of coercion - and in consequence she manages to neutralize completely "the cog theory". As we can read further, "For only if we assume that there exist a human faculty which enable us to judge rationally without being carried away by either emotion or self-interest, and which at the same time functions spontaneously, that is to say, is not bound by standards and rules by which particular cases are simply subsumed, but on the contrary, produces its own principles by virtue of the judging activity itself; only under this assumption can we risk ourselves on this slippery moral ground with some hope of finding a firm footing" (Arendt, 2003, p. 27; cf. Arendt, 2003, pp. 49-146; 2005, pp. 93-200).

$\mathrm{H}$. Arendt has no doubt that in the situation of coercion an individual is still responsible for his or her compliance, and that refusal of judging is an abandonment for which the individual is responsible. For $\mathrm{H}$. Arendt neither political power nor ideology is not able to absorb completely the whole potential of moral resistance of individual or make it functional according to system legitimated by the low of the state. Thus she pay attention to the fact of withdrawal from public life, refusal to participate, to be obedient or at least refusal to support actively the decisions of political leaders. In this sense no political creature does not lose features of being the product created by human hands to the extent that it would not need their active support. "In these terms, the nonparticipators in public life under a dictatorship are those who have refused their support by shunning those places of "responsibility" where such support, under the name of obedience, is required. And we have only for a moment to imagine what would happen to any of these forms of government if enough people would act "irresponsibly" and refuse support, even without active resistance and rebellion, to see how effective weapon this could be" (Arendt, 2003, p. 47).

The grounding of A. Finkielkraut's thought that we tried to reconstruct here may be unnoticed during the lecture of his books because it is rarely exposed, and the references to E. Lévinas and H. Arendt more often serve as illustrations, starting or supporting points for particular questions. Thus his opinions and descriptions of particular situations, but also his reflection on educational practices, perhaps make an impression of chaotic or even controversial ones. Of course this deeper grounding of his reflection does not mean that he can avoid making mistakes while engaging in criticism. Nevertheless revealing this grounding of his thought let us notice a specific pattern of ethical sensibility and an impulse coming from moral philosophy which he uses to his culture criticism. It fosters better understanding of his analyzes of educational practices and the possibility of more substantial discussion with A. Finkielkraut in two aforementioned dimensions.

Let us illustrate with a few examples the way of functioning Lévinas's and Arend's theoretical statements and critical apparatus in Finkielkraut's reflection concerning various modern phenomena that occurs in the social-political and educational spheres.

The necessarily selective presentation of examples we shall begin with Finkielkraut's comments on the contemporary crisis of education. "«Europe is getting older» claims demography. "So where are the adults?» asks anthropology" (Finkielkraut and Sloterdijk, 2005, p.147), following Finkielkraut's remark one can think of another question, 
which makes the former even stronger: what has happened to Immanuel Kant's idea of "man's emergence from his self-incurred immaturity"? Those two questions puts the education crisis issues in a much wider perspective that can be described as a crisis of the idea of maturity. It leads A. Finkielkraut to, as we shall see, to a special mode of interpretation of educational crisis in terms of tradition, responsibility, judgment and justice essential to both his teachers, H. Arendt and E. Lévinas.

When seeking answers in Finkielkraut's work, one might say briefly that the basic problem of contemporary education consists in breaking the ties of tradition. According to Finkielkraut, the break with tradition might be seen as caused among many others by the dissemination of cultural relativism. In The Defeat of the Mind, A. Finkielkraut takes under consideration the large popularity of Lévy-Strauss's structural anthropology that has influenced almost every discipline of human science, also pedagogy. The announcement of equality of all cultures, the ban on comparing them and making judgments, as A. Finkielkraut explains, is strengthened by multiculturalism and so called philosophy of decolonization: "the philosophers of decolonization were speaking for the Other. Settling matters with their own tradition, they tried to do away with illusion of Europeans had delighted in for so long, that their culture had no equal. Instead of the collective me, without hesitation they took the side of the non-me, of the proscribed, the exluded, the outsider" (Finkielkraut, 1995, pp. 65-66).

Despite the very ethical impulses of the philosophy of decolonization, one should then not ignore its most extreme consequences because, as A. Finkielkraut insists on: "Those who thought they have left behind the idea of abstract man in order to embrace the real human being, had, in effect, done away with the space that existed between the individuals and the collectives from which they come, a space that anthropologist in the Enlightment period has insisted upon. Under the guise of altruism they turned the Other into a homogenous bloc, destroying the individual realities of others" (1995, pp.75-76).

With this quotation, we have returned to our previous considerations on A. Finkielkraut's interpretation of E. Lévinas's thinking. It is certainly the idea of justice that is at stake in his critical approach to education. Following E. Lévinas, he points out that an unconditional respect to every way of life, to the Other as any other, without limits, leads to the oblivion of justice, to the fall into irresponsibility.

How then one is to be responsible for the Other, who is a child? It is not difficult to also find references to $\mathrm{H}$. Arendt in Finkielkraut's proposal, which one can summarize this way: when treating children as adults and adults as children, we smudge the differences between those two notions of childhood and maturity. In order to underline the importance of maintaining the difference between those two notions with respect to tradition, A. Finkielkraut quotes H. Arendt in his L'ingratitude: "«It is precisely for keeping in every child what is new and revolutionary, the educational system itself should remain conservative»" (Arendt 1993, p. 223) - says H. Arendt. In his commentary to the following quotation, one can find an answer to I.Kant's question mentioned at the beginning: how is man to emerge from his self-incurred immaturity?: "(...) School discipline pulls out the pupil from the sphere of the present day, a neophyte has to become heir, successor, in order to make his ability to innovate real. The transfer of tradition is an indispensable condition of freedom. School is needed in order to make possible for humankind to exist without educators" (Finkielkraut, 2005, p. 116).

The issue of creating the figure or the image of the Other, which is constantly present in A. Finkielkraut's writings can be located in the perspective of intercultural education. We can trace it starting from The Imaginary Jew (1981), where he considers the questions 
of Jewish identity after Auschwitz, the Holocaust and its memory, anti-Semitism and the Palestinian-Israeli conflict. In his most personal and autobiographical book (The Imaginary Jew), one can read about his Jewish-Polish origins, the impossibility of transferring his familly's shtetl past and tradition which have remained a secret for him (and his generation) Finkielkraut, 1994, p. 10-11. A. Finkielkraut's concept of imaginary Jew emerges as a kind of diagnosis of the condition of Jewish identity after Auschwitz which then needs to be defined by absence, loss, lack of content ${ }^{5}$. As a kind of empty signifier, the imaginary Jew remains open to different kinds of political tensions. And A. Finkielkraut points out briefly the dangers entailed by its susceptibility to diverse abuses: "There's not a single revolt or single struggle of the last forty years that hasn't borne the stamp of antifascism. From the battered woman to the immigrant worker, from the Chilean junta to the children of Cambodia and on to the prisoners of gulag, each victim brings the Jew back to life. The swaggering profile of any opressor cast the shadow of Nazi executioner. The result : a split, a schism between the Jew in the abstract, who functioned as a kind of standard measure for comparing all types of misfortune, and the concrete Jew, neglected in favour of the latest victims" (Finkielkraut, 1997, p. 175).

In the tendencies described above, he sees the reduction of social-political reality to a single stereotype structure of the Victim and the Executioner, Jew and the Nazi that, as he insists on, leads to grave misunderstanding of contemporary antagonisms, struggles and emancipation movements. Misuses of this kind might also be found in intercultural or postcolonial pedagogy.

More than 20 years later, as an author of $A u$ nom de l'Autre. Réflexions sur l'antisémitism gue vient (2003)A. Finkielkraut underscores the most extreme consequences of conceiving and describing the Palestinian-Israeli conflict in those terms. Among other consequences, he points out the rise of the new anti-Semitism rooted in a conviction that Israeli Jews have betrayed their Jewish fate - which is remaining a victim, the Other. The world has discovered that the Israeli women soldier has nothing to do with an imaginary Jew seen as a paradigmatic victim and the Other to whom one ought to provide unconditional respect. To make the way H. Arendt and E. Lévinas provide A. Finkielkraut's commentary with a deep philosophical background more visible, we shall go back to the already quoted dialogue with P. Sloterdijk where one can find some sharp words of a critic directed to the opponents (let's call them the defenders of the Other): „(...) I would like to respond to them following Hannah Arendt, that it is not a man who lives on the Earth, but people in their infinite plurality, and following Lévinas, the philosopher of alterity par excellence, that there is always a danger in subjecting proper names to the rule of common names, even when we mean the Other" (Finkielkraut and Sloterdijk, 2005, p. 34).

The questions of the pluralism of nomes propres and the temptation to reduce them to some kinds of units are also in the foreground of A. Finkielkraut's reflection devoted

5 Henri Raczymow pointes out that Finkielkraut's diagnosis refers most likely to the second or third generation of French Jews whose parents were born in Poland. This is why according to Raczymow one must be aware the limits of category of imaginary Jew: "Unlike Finkielkraut I would not say that Jewish identity is necessarily defined by absence, that it has to be an empty category, something imaginary. For some years now I have been teaching in an orthodox Jewish school, and my students, as become immediately apparent, are nothing but imaginary Jews". Moreover he disagrees with a connection made between Auschwitz and the emergence of the figure of imaginary Jew which in his opinion "predates Holocaust. It has been around for a while, having emerged in the Haskalah, the Jewish enlightenment, with the secularization of the Jews" (Raczymow, 2003, p. 411). 
to the question of the humanity in the work entitled In the Name of Humanity. The impetus for taking under consideration the idea of humanity, so essential to the western educational theory and practice, gave him the questions left by the totalitarianisms of the XX century: "How was it possible for the concept of universal humanity to fall into such massive and radical oblivion in the center of the very civilization where it reached its most spectacular development?" (Finkielkraut, 2000, p. 24).

Referring to the works of $\mathrm{H}$. Arendt and E. Lévinas ${ }^{6}$, both afflicted by the experience of totalitarianism, Finkielkraut investigates profoundly the concept of humanity pointing out the urgent challenge imposed by it: "to preserve the idea of humanity and to make sure the idea does not kill" (Finkielkraut, 2000, p. 83).

We assume that it is placing beyond the pernicious dualism that is at stake in his reflection on the concept of humanity; the dualisms which make us decide: either universal humanity or the concrete identity, either autonomy of the ego or the power of the Other, either "the feeling of gratitude toward what is given or the capacity to think" (Finkielkraut, 2000, p. 103). He says: "All the same - that is, human: each one different - that is, in themselves; together men form a community of exceptions in the word" (Finkielkraut, 2000, p. 80). When reducing the complex human condition to the only part of the alternative, one falls into a trap of sole particularism or racism introduced among others by National Socialism, or in another sort of trap which is the homogenous universalism affirmed earlier by Stalinist Communism. This kind of lesson was given by $\mathrm{H}$. Arendt in The Origins of Totalitarianism, as A. Finkielkraut puts it: "Man in abstract, with no people or place, is nothing more than a man. And as nothing more than a man - as pure consciousness with no attachment or home - he is no longer a man" (2000, p. 101).

In In the Name of Humanity A. Finkielkraut explores the modern attempts to respond to the horror of two totalitarianisms and to reinterpret the notion of humanity in terms of the logic of "sentimental reason" (2000, p. 87). We shall follow his reflection which paradoxically, at least at first glance, turns out to be the criticism of humanitarianism providing the concept of the humanity based on suffering, which is also present in conceptions developed within social pedagogy, but not only there. When criticizing the philosophical ground of humanitarianism, with its organizations like the International Red Cross, he pays attention to its basic principle which is neutrality. Concerning the activity of the International Red Cross Finkielkraut writes: "Its authority rested solely in being above all controversies that led to conflict, be they political, philosophical, racial, or religious. In refusing to choose among the unfortunate wounded, it refuses to choose among the actors as well judge the conduct of governments" (2000, pp. 85-86).

The price to pay for the refusal of judgment which places the humanitarian practice beyond the social-political sphere is too high - insists Finkielkraut. When offering the spontaneous and expedient aid to the concrete people, to those people not the other, one has already chosen despite declared neutrality that provide rescue no matter whom, which means the victim.

A. Finkielkraut raises one's awareness of the fact that being a human in need is not enough to receive help even if this is what humanitarians believe in. There are always

6 They both share experience of surviving the Holocaust. H. Arendt escaped from Germany to France and then in 1941 to United States where she settled down (Brudny, 2006, pp. 71-140). She became a refugee. For account of a figure of refugee in Arendt's writings see "Biopolitics and the Right of Man" Agamben, 1998, pp.126-136. Lévinas spend five years of War imprisoned in Stalag as Jewish-French soldier what saved his life (Malka, 2005, pp.83-87). 
the several decisions to be made, related to politics, culture, and many other factors: we are always to judge who is a victim, who should receive our aid first. One should not ignore the need for decisions even when believing in the ideology of the heart, promising rushed aid to all the sufferers in the word. Simply because, as A. Finkielkraut points out: "Joining the humanitarian side and supporting the victims does not mean, despite appearances, that we made the right choice. No matter what we do, it is risky and uncertain" (2000, p. 93).

$$
* * *
$$

As we have shown in his writings, A. Finkielkraut keeps reminding us that the risk and the uncertainty are indispensable component of judgment. We have also attempted to grasp the connection between two crucial issues: his ethical-political reading of E. Lévinas's, as well as H. Arendt's thought on the one hand, and his critical approach applied to investigate educational practices, social-cultural situations, states and events. This way we hope to have revealed not only the theoretical basis of his reflection on educational practices, but also critical apparatus oriented toward diagnosing educational practices in reference to the condition of contemporary inhabitant of the western world, recognized in a crisis of responsibility and the power of judgment.

\section{REFERENCES}

Agamben, G. (1998). Biopolitics and the Rights of Man. In: G. Agamben (Ed.), Homo Sacer. Sovereign Power and Bare Life (pages of chapter).. Stanford: Stanford University Press. Arendt, H. (1973). The Origins of Totalitarianism. New York: Harcourt, Brace, Jovanovich.

Arendt, H. (1993). Between Past and Future. Eight Exercises in Political Thought. New York: Penguin.

Arendt, A. (1995). Eichmann in Jerusalem. A Report on the Banality of Evil. New York: Penguin.

Arendt, H. (1998). The Human Condition. Chicago and London: The University of Chicago Press.

Arendt, H. (2003). Responsibility and Judgment. New York: Schocken.

Arendt, H. (2005). The Promise of Politics. New York: Schocken.

Aschheim, S.E. (Ed.) (2001). Hannah Arendt in Jerusalem. Berkeley, Los Angeles, London: University of California Press.

Brudny, M.-I. (2006). Hannah Arendt: Essai de biographie intellectuelle. Grasset \& Fasquelle.

Finkielkraut, A. (1984). La sagesse de l'amour. Paris: Gallimard.

Finkielkraut, A. (1994). The Imaginary Jew. Nebraska: University of Nebraska Press.

Finkielkraut, A. (1995). The Defeat of the Mind. . New York: Columbia University Press.

Finkielkraut, A. (1998). Présentation. In: J. Halpérin, \& N. Hansson (Eds.). Difficile justice. Dans la trace d'Emmanuel Lévinas (numery stron rozdzialu). Paris: Éditions Albin Michel.

Finkielkraut, A. (2000). In the Name of Humanity. New York: Columbia University Press.

Finkielkraut, A. (2003). Au nom de l'Autre. Réflexions sur l'antisémitism qui vient. Paris: Gallimard.

Finkielkraut, A. (2005). Niewdzięczność. [Ingratitude]. Warszawa: Sic!.

Finkielkraut, A., \& Simon-Nahum, P. (2005). “«Savoir se souvenir». Entretien avec Alain Finkielkraut.” Le Magazine Littéraire, 445. 
Finkielkraut, A., \& Sloterdijk, P. (2005). Les battements du monde. Paris: Fayard.

Lévinas, E. (1990). Difficult Freedom. Essays on Judaism.. Baltimore: The Johns Hopkins University Press.

Lévinas, E. (1991). Otherwise than Being: or Beyond Essence. Miasto: Kluwer Academic Publishers.

Lévinas, E. (1992). Totality and Infinity. An Essay on Exteriority. Pittsburgh: Duquesne University Press.

Lévinas, E. (1994). The Bible and the Greeks. In: E. Lévinas,(Ed.), In the Time of Nations. London: The Athlone Press Lévinas, E. (1998). Of God who Comes to Mind. Stanford: Stanford University Press.

Lévy, Z. (1999). L’hébreu et le grec comme métaphores de la pensée juive et de la philosophie dans la pensée d'Emmanuel Levinas. Pardès, 26.

Malka, S. (2005). Emmanuel Lévinas. La vie et la trace. Paris: Éditions Albin Michel.

Raczymow, H. (2003). Memory Shot Through with Holes. In: N. Levi, \& M. Rothberg (Eds.). The Holocaust. Theoretical Readings. Edinburgh: Edinburgh University Press. 